\title{
Comparison Between Key Success Factors in Safety Behavior in Small- and Medium-Sized Enterprises (SMEs) and Large Industries, and Development of a Hypothetic Model for Safety Behavior in Indonesian SMEs
}

\section{Nachnul Ansori¹,2, Iftikar Zahedi Sutalaksana ${ }^{1}$, and Ari Widyanti}

1Department of Industrial Engineering and Management, Bandung Institute of Technology, Jl. Ganesha No.10, Lb. Siliwangi, Coblong, Kota Bandung, Jawa Barat 40132, Indonesia ${ }^{2}$ Department of Industrial Engineering, University of Trunojoyo Madura, Jl. Raya Telang, Kecamatan Kamal, Bangkalan, Telang, Kamal, Madura, Jawa Timur 69162, Indonesia

\section{Abstract}

The distinct characteristic between SMEs and large industries indicates a difference in

Corresponding Author:

Nachnul Ansori

nachnul@gmail.com

Received: 15 May 2018

Accepted: 3 June 2018

Published: 19 June 2018

Publishing services provided by Knowledge $\mathrm{E}$

(c) Nachnul Ansori et al. This article is distributed under the terms of the Creative Commons

Attribution License, which

permits unrestricted use and redistribution provided that the original author and source are credited.

Selection and Peer-review under the responsibility of the ICOHS 2017 Conference Committee. the Key Success Factor (KSF) in safety behavior that must be considered. The purpose of this article is to identify possible differences in KSF between SMEs and large industries. The identification of KSFs is used to avoid the focal point of attention to critical elements that is taken into account in efforts to implement safety improvement programs and it is conducted through a literature study. The result of the research shows that there are differences between KSFs in SMEs and large industries, although some KSFs represent the characteristics of both industries. In addition, a hypothetic model of the influence of KSFs to safety behavior in SMEs is proposed.

Keywords: key success factors, safety behavior, SMEs

\section{Introduction}

Occupational accidents occur in industries generally caused by unsafe behavior [1]. For examples, Khandan [2] points out that 86 to 96 percent of accidents can be prevented and occurs due to unsafe behavior. In another study conducted by Al-Hemoud and AlAsfoor [3], it was estimated that 88 percent of occupational accidents were caused by unsafe activity, 10 percent due to unsafe conditions, and only 2 percent due to unavoidable factors.

Occupational accidents that are caused by unsafe behavior occur on different industrial scales, both on small and large-scale of industries. Therefore, it is crucially important to investigate critical factors that trigger the occurrence of an unsafe behavior. 
In particular, the importance of investigation of the critical factors is supported by the fact that safety behavior is an important aspect of occupational safety [4].

According to Shin et al. [5], Soe et al. [6], Amponsah-Tawaih \& Adu, [7], Guo et al. [8], and Panuwatwanich et al. [9], safety behaviors can be defined as behaviors that support safety activities required by workers to meet the Occupational Health and Safety (OHS) that are needed to avoid accidents. The dimensions used to describe safety behaviors are safety participation and safety compliance [10]. Safety participation concerned with helping peers, supporting safety programs, initiatives and efforts to improve safety at work, while safety compliance refers to safety procedures and performing work activities in a safe manner $[6,10]$. Safety behavior can consequently decrease accident rates, injuries, and lost working time [6].

Efforts to improve safety behavior start by investigating influential variables as key success factors (KSFs) that contribute to safety behavior [11]. Unfortunately, the differences in industrial characteristics, especially in SMEs with large-scale industry makes the generalization of KSF cannot be applied. There are many research models of safety behavior developed in large industries. In contrast, no model of safety behavior in SMEs can be found.

In Indonesia, the contribution of SMEs in reducing a number of unemployment and Indonesian gross domestic product is crucial, any effort in increasing productivity and enhancing safety in SMEs is worth noting [12]. Thus, safety behavior issues also arise in SMEs.

This article aimed to identify possible differences in KSF in safety behavior between SMEs and large industries. The identification of KSFs, both for SMEs and large-scale industries is used to avoid the focal point of attention to critical elements that taken into account in efforts to implement the safety improvement programs. A hypothetic model of the influence of KSFs to safety behavior in SMEs is proposed.

\section{Methods}

Identification and comparison of KSFs in safety behavior between SMEs and large industries were conducted through a literature study. Literature searches were performed on major publishers such as Elsevier (www.sciencedirect.com), Emerald (www.emeraldinsight.com), Springer (www.springerlink.com), Wiley (www. wiley.com), library services (e.g., Scopus; www.scopus.com) or google scholar. Based on the literature review, five papers were found in relation to the SME' safety behavior factors and nine papers were found in relation to the model of safety behavior 
within the recent two years of publications. Other 10 papers related to SMEs' OHS performance were reviewed to link and match all factors with the parameters of conformity of both driving factors and barriers from OHS' papers. Finally, a hypothetic model of SMEs' safety behavior was proposed based on a model of Soe et al. [6], combined with the unique characteristic of the SMEs.

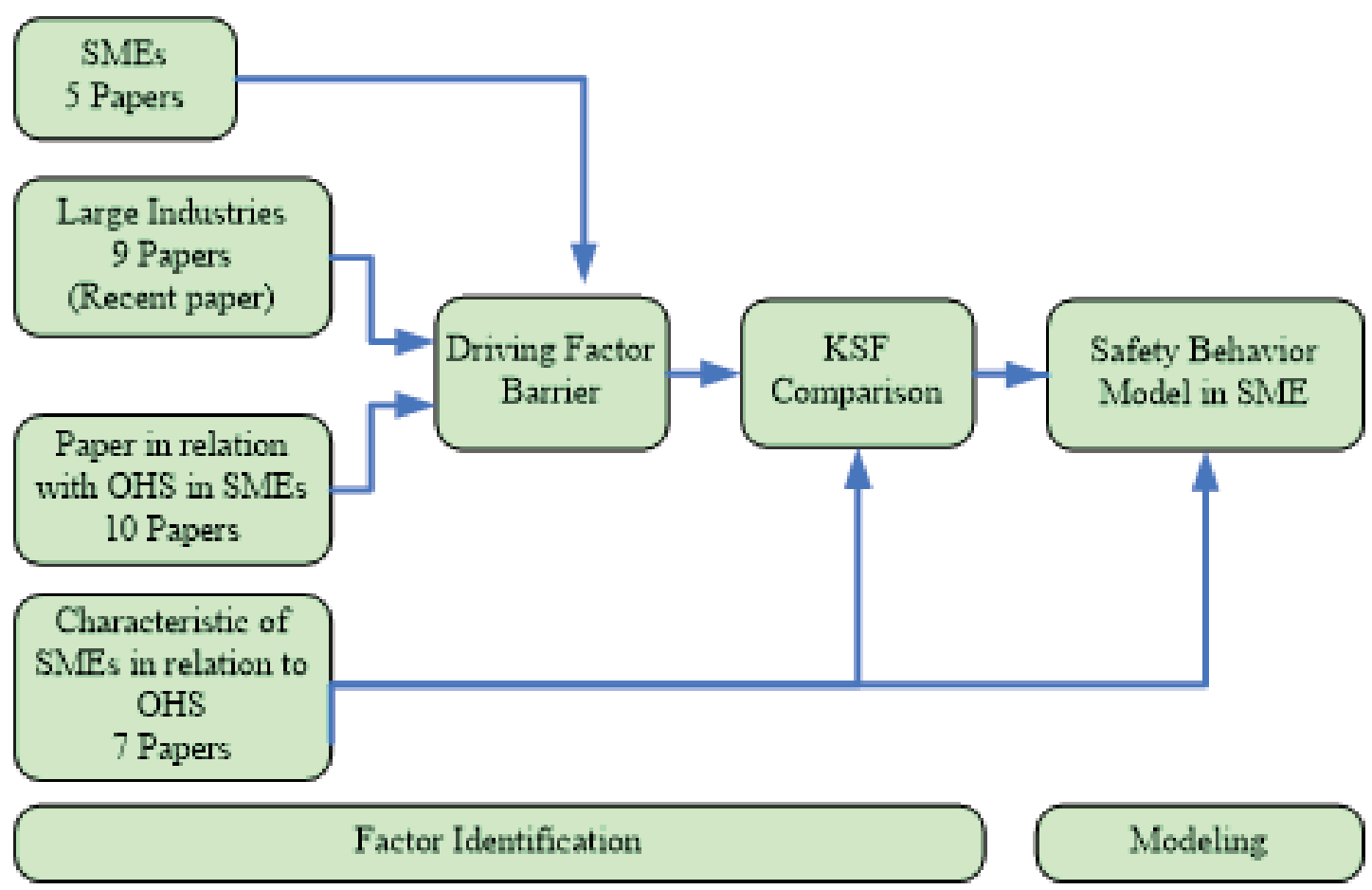

Figure 1: Flow chart of research.

\section{Results}

Based on a literature study, since there is no model of safety behavior exist in SMEs, in general, KSFs in SMEs are divided into individual factors and organizational factors. As can be seen in Table 1 that several studies have obtained factors that contribute to the safety behaviors performed in some countries, such as Malaysia, China, and Indonesia.

Meanwhile, KSFs in large industries are identified based on existing safety behavior models. Table 2 shows several studies concerning the large-scale industrial safety behavior model as a reference in the study to describe what factors affect the safety behavior. The line business of industries is not only manufacturing but also in services industries.

In addition, from the identification process, Figure 2 shows the comparison between KSFs of SMEs' safety behavior and large-scale industries. Base on Figure 2, a hypothetic 
model for safety behavior in SMEs is proposed as can be seen in Figure 3. In Figure 3 show a mapping of factors that affect safety behavior as a special characteristic possessed by SMEs.

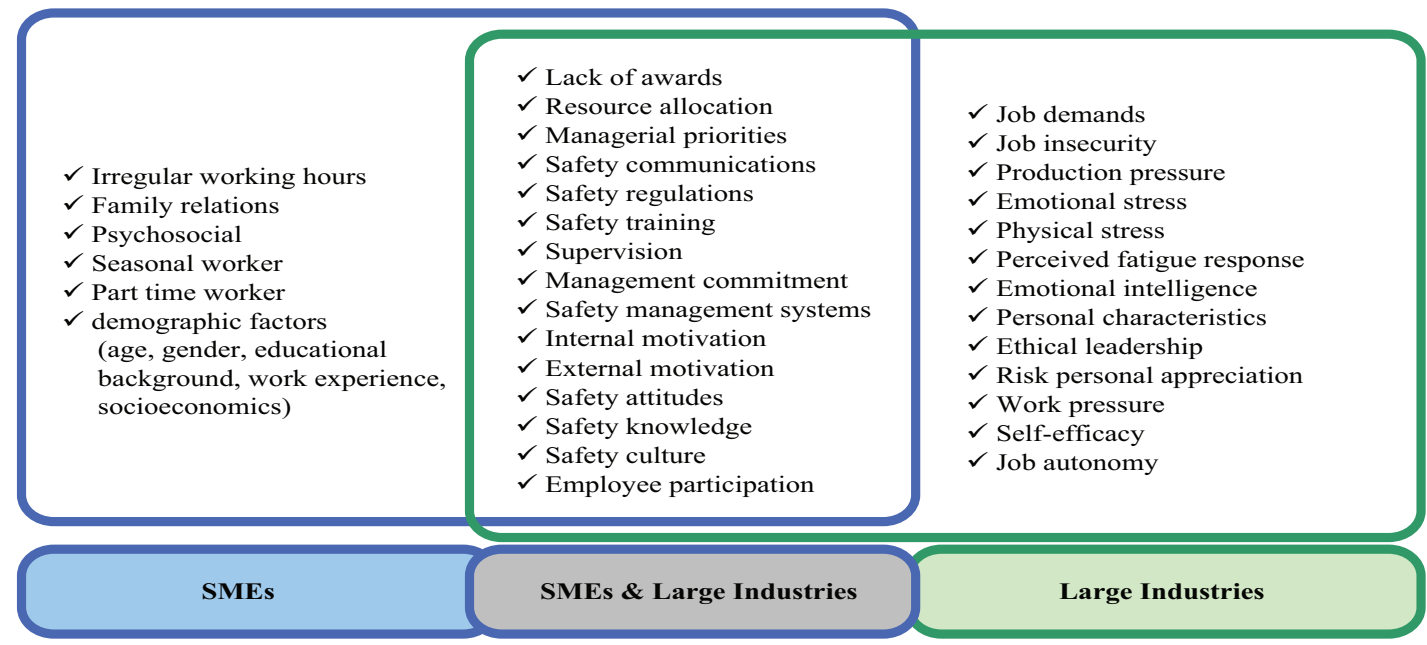

Figure 2: Classification of SMEs' KSF and large industries' KSF on safety behavior.

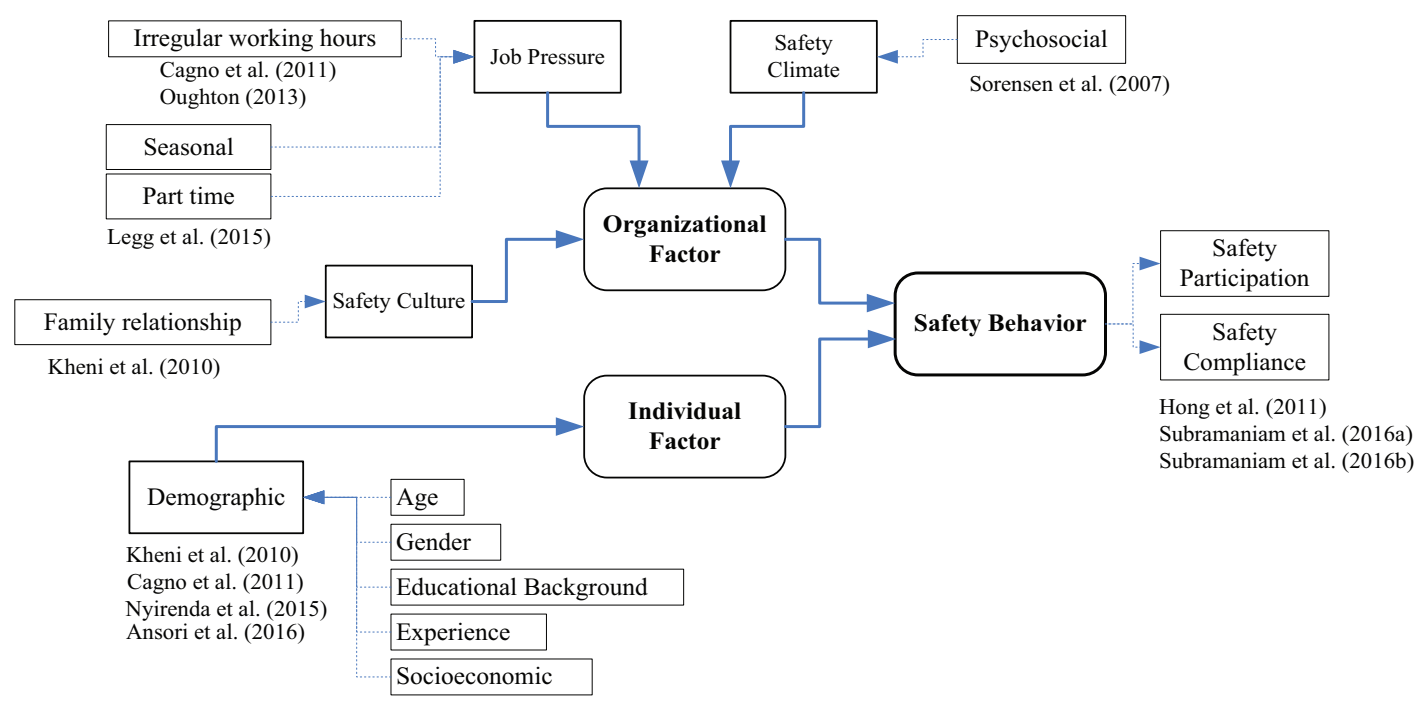

Figure 3: Model of safety behavior in SMEs based on KSFs.

\section{Discussion}

This article is purposed to identify KSFs in safety behavior in SMEs compared to ones in large industries. The identified KSFs are then used to develop a hypothetical model of safety behavior in SMEs. This article is particularly important as stated by Cagno et al. [18], the implementation of SMEs' safety performance needs attention due to the fact that SMEs safety management practices are not yet well-established and still require 
TABLE 1: SMEs' safety behavior factors.

\begin{tabular}{|c|c|c|c|}
\hline Research & Object & Method & Factor \\
\hline $\begin{array}{l}\text { Subramaniam } \\
\text { et al. }[13,14]\end{array}$ & SMEs Malaysia & $\begin{array}{l}\text { Study of } \\
\text { Literature }\end{array}$ & $\begin{array}{l}\text { Management commitments, safety } \\
\text { communications, safety training, } \\
\text { employee engagement, safety } \\
\text { regulations, managerial priorities }\end{array}$ \\
\hline Hong et al. [15] & SMEs Malaysia & $\begin{array}{l}\text { Correlation } \\
\text { Analysis }\end{array}$ & $\begin{array}{l}\text { Safety training, employee } \\
\text { engagement, safety regulations }\end{array}$ \\
\hline Liu et al. [16] & SMEs China & $\begin{array}{l}\text { Study of } \\
\text { Literature }\end{array}$ & $\begin{array}{l}\text { Managerial priorities, safety culture, } \\
\text { internal motivation, safety } \\
\text { knowledge }\end{array}$ \\
\hline Ansori et al. [17] & SMEs Indonesia & Factor Analysis & $\begin{array}{l}\text { Managerial priorities, safety } \\
\text { knowledge, resource allocation, } \\
\text { supervision, safety attitudes }\end{array}$ \\
\hline
\end{tabular}

practice and increased safety awareness [19]. SMEs constraints and limitations make OHS modern rules in large industries and their interventions cannot be automatically applied to SMEs [20]. Several OHS studies of SMEs [18, 21-30] are inventoried to obtain all the attributes of constraints and drivers of SMEs' OHS performance.

SMEs have unique characteristics in relation with KSFs that cannot be found in large industries such as the high heterogeneity in demographic factors (age, gender, educational background and work experience $[11,17,21,35]$. In addition, Kheni et al. [21] state that the low socioeconomic conditions of SMEs workers as a uniqueness that can hamper the achievement of SMEs' OHS performance. Furthermore, the nonfixed/scheduled work time in SMEs is claimed as a factor that affects the accidents [36]. In relation to SMEs work time, Cagno et al. [35] stated that working time conditions in irregular working hours on SMEs can affect the performance of SMEs' OHS.

Research by Kheni et al. [21] states that family relationships can lead to poor OHS management, any tendency for tolerance in the application of OHS rules. The character of seasonal and part-time work in SMEs makes it difficult to implement OHS rules. Meanwhile, Sorensen et al [37] point out that psychosocial factor in SMEs is higher than the large one. It can accordingly affect the quality of OHS performance. Thus, psychosocial has an important role in preventing an occupational accident.

Modeling is a process to represent the real system more simply, where the goal is to perform prediction analysis of system changes [38]. In the proposed hypothetic safety behavior model of SMEs, it described causality between one factor with other factors. In which KSFs represent independent variables while safety behavior represents a dependent variable. Modeling of SMEs safety behavior based on SMEs' KSF is required 
TABLE 2: Large industries' safety behavior model.

\begin{tabular}{|c|c|c|c|}
\hline Research & Object & Method & Factor \\
\hline Chughtai [31] & Hospital & SEM & $\begin{array}{l}\text { Ethical leadership, self-efficacy, job } \\
\text { autonomy }\end{array}$ \\
\hline Shin et al. [5] & $\begin{array}{l}\text { Construction } \\
\text { Industry }\end{array}$ & EFA \& CFA & $\begin{array}{l}\text { Communication safety, safety } \\
\text { training }\end{array}$ \\
\hline Soe et al. [6] & $\begin{array}{l}\text { Construction } \\
\text { Industry }\end{array}$ & SEM & $\begin{array}{l}\text { Job demands, job insecurity, lack of } \\
\text { respect, global fatigue, daily } \\
\text { dysfunction, situational exhaustion, } \\
\text { managerial priority, safety } \\
\text { communications, safety regulations, } \\
\text { safety training, personal } \\
\text { characteristics, safety culture }\end{array}$ \\
\hline $\begin{array}{l}\text { Amposah-Tawaih } \\
\text { et al. [7] }\end{array}$ & Hospital & $\begin{array}{l}\text { Multiple } \\
\text { Regression } \\
\text { Analysis }\end{array}$ & $\begin{array}{l}\text { Job demands, safety } \\
\text { communications, safety training, } \\
\text { personal appreciation of risk, } \\
\text { internal motivation, safety } \\
\text { knowledge, management } \\
\text { commitment }\end{array}$ \\
\hline Guo et al. [8] & $\begin{array}{l}\text { Construction } \\
\text { Industry }\end{array}$ & SEM & $\begin{array}{l}\text { Production pressure, internal } \\
\text { motivation, external motivation, } \\
\text { safety knowledge, management } \\
\text { commitment }\end{array}$ \\
\hline Lu \& Kuo [32] & $\begin{array}{l}\text { Container } \\
\text { Terminal }\end{array}$ & $\begin{array}{l}\text { Hierarchical } \\
\text { Regression } \\
\text { Analysis }\end{array}$ & $\begin{array}{l}\text { Stress emotions, physical stress, } \\
\text { emotional intelligence }\end{array}$ \\
\hline $\begin{array}{l}\text { Panuwatwanich } \\
\text { et al. [9] }\end{array}$ & $\begin{array}{l}\text { Construction } \\
\text { Industry }\end{array}$ & EFA \& CFA & $\begin{array}{l}\text { Safety communication, safety } \\
\text { regulations, safety training, } \\
\text { personal appreciation of risk, work } \\
\text { pressure, internal motivation, } \\
\text { external motivation }\end{array}$ \\
\hline Baser et al. [33] & Hotel & SEM & Safety attitude, safety knowledge \\
\hline $\begin{array}{l}\text { Mohammadfam } \\
\text { et al. [34] }\end{array}$ & $\begin{array}{l}\text { Construction } \\
\text { Industry }\end{array}$ & $\begin{array}{l}\text { Bayesian } \\
\text { Network } \\
\text { Approach }\end{array}$ & $\begin{array}{l}\text { External motivation, safety attitude, } \\
\text { safety knowledge, worker } \\
\text { participation }\end{array}$ \\
\hline
\end{tabular}

to test whether the KSF will significantly influence safety behavior. In addition, the model can be used to predict SMEs safety behavior.

\section{Conclusions}

SMEs has different KSFs from large industries. This implies that the focus of attention on efforts to improve safety behavior between SMEs and large industries are different. Several existing factors and indicators can be used as a benchmark for safety behavior in SMEs. The findings of the KSFs is used as a guide to establish a model of SME safety behavior which is required to predict safety behavior in SMEs, so that effort to provide 
safety in SMEs can be in the right track. Further studies will be conducted to validate the KSFs in the proposed model, in particular, field studies in SMEs to confirm the KSFs and to analyze the result based on the proposed model. With further studies, the generalization of the model is expected in order to maximize utilization the model of SMEs safety behavior in Indonesia.

\section{Conflict of Interest}

The authors declare that they have no competing interest.

\section{Funding}

The research is funded by Indonesia Endowment Fund for Education (LPDP)-Ministry of Finance through doctoral program scholarship.

\section{References}

[1] Seo, D. (2005). An explicative model of unsafe work behavior. Safety Science, vol. 43, pp. 187- 211.

[2] Khandan, M., Maghsoudipour, M., Vosoughi, S., et al. (2013). Safety climate and prediction of ergonomic behavior. International Journal of Occupational safety and Ergonomic, vol. 19, pp. 523-530.

[3] Al-Hemoud and Al-Asfoor. (2006). A behavior based safety approuch at a Kuwait Research Institution. Journal of Safety Research, vol. 37, pp. 201-206.

[4] Geller, E. S. (2000). The Psychology of Safety Handbook. CRC Press.

[5] Shin, D., Gwak, H., and Lee, D. (2015). Modeling the predictors of safety behavior in construction workers. International Journal of Occupational Safety and Ergonomics, vol. 21, pp. 298-311.

[6] Soe, H., Lee, Y., Kim, J., et al. (2015). Analyzing safety behavior of temporary construction workers using structural equation modeling. Safety Science, vol. 77, pp. $160-168$.

[7] Amponsah-Tawaih, K. and Adu, M. A. (2016). Work pressure and safety behaviors among health workers in Ghana: The moderating role of management commitment to safety. Safety and Health at Work, vol. 7, pp. 340-346. 
[8] Guo, B. H. W., Yiu, T. W., and Gonzalez. (2016). Predicting safety behavior in the construction industry: Development and test of an integrative model. Safety Science, vol. 84, pp. 1-11.

[9] Panuwatwanich, K., Al-Haadir, S., and Stewart, R. A. (2016). Influence of safety motivation and climate on safety behavior and outcomes: Evidence form the Saudi Arabian Construction Industry. International Journal of Occupational Safety and Ergonomics, vol. 23, pp. 60-75.

[10] Neal, A., Griffin, M. A., and Hart, P. M. (2000). The impact of organizational climate on safety climate and individual behavior. Safety Science, vol. 34, pp. 99-109.

[11] Nyirenda, V., Chinniah, Y., and Agard, B. (2015). Identifying key factors for an occupational health and safety risk estimation tool in small and medium-size enterprises. International Federation of Automatic Control, vol. 48, pp. 541-546.

[12] BPS. (2016). Indonesian Statistical Bureau.

[13] Subramaniam, C., Shamsudin, F. M., Zin, M. L., et al. (2016a). Safety management practices and safety compliance: A model for SMEs in Malaysia. International Soft Science Conference, pp. 2357-1330.

[14] Subramaniam, C., Shamsudin, F. M., Zin, M. L., et al. (2016b). The influence of safety management practices on safety behavior: A study among manufacturing SMES in Malaysia. International Journal Supply Chain Management, vol. 5, pp. 148-160.

[15] Hong, K. T., Surienty, L., and Hung, D. K. M. (2011). Safety management practices and safety behaviour: A preliminary investigation in Malaysian small and medium enterprises in Northern Corridor Economic Region (NCER). Journal Occupational Safety \& Health, vol. 8, pp. 1-11.

[16] Liu, S., Mei, Q., and Shen, B. (2010). A safety management mode for small and medium-sized enterprise based of safety behavior. International Conference on EBusiness and E-Government, pp. 2367-2370.

[17] Ansori, N., Novianti, T., and Agustina, F. (2016). Designing ergonomic participatory based on critical safety performance index in batik creative industries. The $2^{\text {nd }}$ International Conference on Science, Technology and Interdiciplinary Research (ICSTAR). Bandarlampung-Indonesia.

[18] Cagno, E., Micheli, G. J. L., Jacinto, C., et al. (2014). An interpretive model of occupational safety performance for small and medium-sized enterprises. International Journal of Industrial Ergonomics, vol. 44, pp. 60-74.

[19] Unnikrishnan, S., Iqbal, R., Singh, A., et al. (2016). Safety management practices in small and medium enterprises in India. Safety and Health at Work, vol. 6, pp. 46-55. 
[20] Legg, S. J., Olsen, K. B., Laird, I. S., et al. (2015). Managing safety in small and medium enterprises. Safety Science, vol. 71, pp. 189-196.

[21] Kheni, N. A., Gibb, A. G. F., Dainty, A. R. J. (2010). ASCE: Health and safety management within Small and Medium Sized Enterprises (SMEs) in developing countries: Study of contextual influences. Journal of Construction Engineering and Management, vol. 136, pp. 1104-1115.

[22] Micheli, G. J. L. and Cagno,E. (2010). Dealing with SMEs as whole in OHS issue: Warning from empirical evidence. Safety Science, vol. 48, pp. 729-733.

[23] Xiongjun, Y. and Kaiqan, W. (2012). Study on safety management of small and medium-sized enterprises based on BBS. International Symposium on Safety Science and Technology. Procedia Engineering, vol. 45, pp. 208-213.

[24] Kines, P., Andersen, D., Andersen, L. P., et al. (2013). Improving safety in small enterprises through an integrated safety management intervention. Journal of Safety Research, vol. 44, pp. 87-95.

[25] Hermawati, S., Lawson, G., and Sutarto, A. P. (2014). Mapping ergonomic application to improve SMEs working condition in industrially developing countries: A critical review. Ergonomics.

[26] Ansori, N., Novianti, T., Agustina, F., et al. (2015a). Safety performance index in batik industry based on multiple criteria (Safety performance index pada industri batik tulis berdasarkan kriteria majemuk). Jurnal Teknik Industri, vol. 17, pp. 105-110.

[27] Ansori, N., Novianti, T., Agustina, F., et al. (2015b). Evaluation of occupational health and safety (OHS), in Batik Putra Madura's SME by Behavior Based Safety (BBS) ((Evaluasi kesehatan dan keselamatan kerja (K3)UKM Batik Putra Madura dengan Behavior Based Safety (BBS)). Proceedings of National Seminar in Sustainable Ergonomic for Better Human Well-Being. Atma Jaya University of Jogjakarta: $\mathrm{H}_{25} 5 \mathrm{H}_{30}$.

[28] Masi, D. and Cagno, E. (2015). Barrier to OHS interventions in small and mediumsized enterprises. Safety Science, vol. 71, pp. 226-241.

[29] Nielsen, K. J., Kines, P., Pedersen, L. M., et al. (2015). A multi-case study of the implementation of an integrated approach to safety in small enterprises. Safety Science, vol. 71, pp. 142-150.

[30] Agustina, F., Ansori, N., Novianti, T., et al. (2016) Ergonomic intervention model by sampling inspection and personal protective equipment. Proceedings The $1^{\text {st }}$ International Joint Conference on Science and Technology (IJCST). Bali-Indonesia.

[31] Chughtai, A. A. (2015). Creating safer workplaces: The role of ethical leadership. Safety science, vol. 73, pp. 92-98. 
[32] Lu, C. and Kuo, S. (2016). The effect of job stress on self-reported safety behavior in container terminal operations: The moderating role of emotional intelligence. Transportation Research Part F, vol. 37, pp. 10-26.

[33] Baser, F., Ture, H., Abubakirova, A., et al. (2016). Structural modeling of the relationship among food safety knowledge, attitude and behavior of Hotel Staff in Turkey. Food Control, vol. 73, pp. 438-444.

[34] Mohammadfam, I., Ghasemi, F., Kalatpour, O., et al. (2017). Constructing a Bayesian network model for improving safety behavior of employees at workplaces. Applied Ergonomics, vol. 58, pp. 35-47.

[35] Cagno, E., Micheli, G. J. L., and Perotti, S. (2011). Identification of OHS-related factors and interactions among those and OHS performance in SMEs. Safety Science, vol. 49, pp. 216-225.

[36] Oughton, N. (2013). Managing occupational risk in creative practice: A new perspective for occupational health and safety. Archives of Environmental \& Occupational Health, vol. 68, pp. 47-54.

[37] Sørensen, O. H., Hasle, P., and Bach, E. (2007). Working in small enterprises - Is there a special risk? Safety Science, vol. 45, pp. 1044-1059.

[38] Maria, A. (1997). Introduction to modeling and simulation. Winter Simulation Conference. 